\title{
Craft Production as an Empowering Strategy in an Emerging Empire
}

By: Donna J. Nash

Nash, D. J. 2019. Craft Production as an Empowering Strategy in an Emerging Empire. Journal of Anthropological Research 75(3): 328-360. https://doi.org/10.1086/704144

Made available courtesy of University of Chicago Press: https://doi.org/10.1086/704144

***: 2019 by The University of New Mexico. Reprinted with permission. No further reproduction is authorized without written permission from University of Chicago Press.***

\begin{abstract}
:
The activities associated with palaces provide clues to understanding the strategies leaders in prehistoric polities used to accrue power. Controlling craft specialists who make prestige goods is one such tactic. Many models presume preciosities were distributed to build alliances or for exchange; however, some objects may be imbued with sacred power. These singular goods would have a different distribution than prestige goods. The relations of production may also differ; elites, rather than attached specialists, may have produced singular objects as an empowering strategy. I propose that some elites in the Wari Empire (600-1000 ce) made elaborate pottery, some of which were sacred goods essential for the performance of rituals, in order to exclude others from this important source of power. To support this hypothesis, I describe the regional distribution of decorated pottery, the manner of its deposition, and evidence that elites created ceramic vessels in a Wari provincial palace at Cerro Baúl, Peru.
\end{abstract}

Keywords: craft specialization | Andes | elite strategies | palaces | pottery production | ritual Article:

$* * *$ Note: Full text of article below 


\title{
Craft Production as an Empowering Strategy in an Emerging Empire
}

\author{
D O N NA J. NASH, Department of Anthropology, University of North Carolina Greensboro, \\ 439 Graham Building, Greensboro, NC 27402, USA. Email: djnash@uncg.edu
}

\begin{abstract}
The activities associated with palaces provide clues to understanding the strategies leaders in prehistoric polities used to accrue power. Controlling craft specialists who make prestige goods is one such tactic. Many models presume preciosities were distributed to build alliances or for exchange; however, some objects may be imbued with sacred power. These singular goods would have a different distribution than prestige goods. The relations of production may also differ; elites, rather than attached specialists, may have produced singular objects as an empowering strategy. I propose that some elites in the Wari Empire (600-1000 CE) made elaborate pottery, some of which were sacred goods essential for the performance of rituals, in order to exclude others from this important source of power. To support this hypothesis, I describe the regional distribution of decorated pottery, the manner of its deposition, and evidence that elites created ceramic vessels in a Wari provincial palace at Cerro Baúl, Peru.
\end{abstract}

Key words: craft specialization, Andes, elite strategies, palaces, pottery production, ritual

Elite residences provide valuable data about prehistoric complex societies because they offer clues to understanding the strategies employed by the privileged to accrue power (Christie and Sarro 2006; Flannery 1998; Inomata and Houston 2001). The hosting of feasts and the distribution of prestige goods are strategies that have received a great deal of attention from archaeologists studying ancient states. In the Andes, consumption wares, such as decorated cups and bowls, have been linked to both strategies so that "feasting wares" are seen to represent both feasting and the distribution of decorated pottery as prestige goods to subordinates. These presumptions are sound when they are supported by other evidence, such as the association with a large feast kitchen (Morris et al. 2011; Topic 2009:222) or the presence of large or oversized serving vessels in areas seemingly designed for gatherings (Isbell 2007). Such interpretations have dominated ideas about the Wari Empire, yet other strategies may also have been important.

In this paper, I describe an elite residential compound at Cerro Baúl, a provincial center located on the southern frontier of the Wari Empire (600-1000 CE) in Moquegua, Peru, as well as the distribution of decorated pottery among subordinate

Submitted November 17, 2017; accepted July 18, 2018; published online July 11, 2019. Journal of Anthropological Research (Fall 2019). (C) 2019 by The University of New Mexico. All rights reserved. 0091-7710/2019/7503-0002\$10.00 
elites in the region. As the most elaborate dwelling in the province during the ninth century, the palace was the setting of political gatherings and lavish feasts. It also included work areas where elites produced decorated pottery. Since these vessels were not widely distributed to subordinate elites and were deposited in ritualized ways, I consider the possibility that they were powerful insignia or ritual paraphernalia rather than prestige goods. I suggest that elites chose to make decorated pottery because of its role in ritual activities as one of many strategies to accumulate power. Performing rituals with these sacred goods may have helped sanction the prerogative to command labor and resources from regional subordinates, who may have received other types of gifts but for the most part were not routinely given elaborate drinking vessels. If this was the case, then the presence of elaborate cups may not represent a gift economy and their absence may not signify that the Wari failed to control a specific community. I return to these broader implications below.

\section{THE WARI EMPIRE}

The Wari Empire of Peru was an expansive polity with affiliated sites found in many highland and coastal areas between Cajamarca and Moquegua (Figure 1). ${ }^{1}$ The polity may have controlled entire regions or selectively wielded power over patches of people and specific resources (see Stanish 2003). In either case, Wari officials manipulated local economies (Schreiber 1992; Keeley and Meddens 1993), invested in massive construction projects (McEwan 2005; Moseley et al. 2005), and influenced many groups (Ángeles 2008; Rosas 2007).

Researchers typically infer "influence" via the presence of decorated Wari pottery because, implicitly or explicitly, they are applying the model of wealth finance or envisioning the gifting of durable goods as a means to suborn intermediate elites (e.g., Covey et al. 2013; Earle and Jennings 2012; Lau 2005). Across the Andes, decorated Wari pottery shares some common attributes but also exhibits local features (Cook 2004). Menzel (1968) noted that many Wari style vessels found in the provinces were made with local pastes. Recent chemical analyses support her observations (Glowacki 2005; Sharratt et al. 2009; Williams et al. 2019). Empires, including the Inka, usually have a similar pattern of variation and local production (e.g., D'Altroy and Bishop 1990; Glatz 2013). Despite documenting notable differences between provinces, Menzel found a certain consistency in what she called "ceremonial" ceramics and postulated that Wari exerted some control over the production of these vessels. Assessing the idea that the production of "ceremonial" ceramic vessels was controlled by the Wari state requires more research in several regions of the empire, but it is important to note that the decorated vessels in question are not widely distributed. Also, many seem to be of a low standard, which might indicate they are "knock-offs" rather than legitimate imperial wares. Since researchers consider these variables when judging if an area was under Wari control, it is worth examining these issues and their implications. The example from Cerro Baúl I describe here provides an opportunity to explore the relations of production and the manner of distribution deter- 


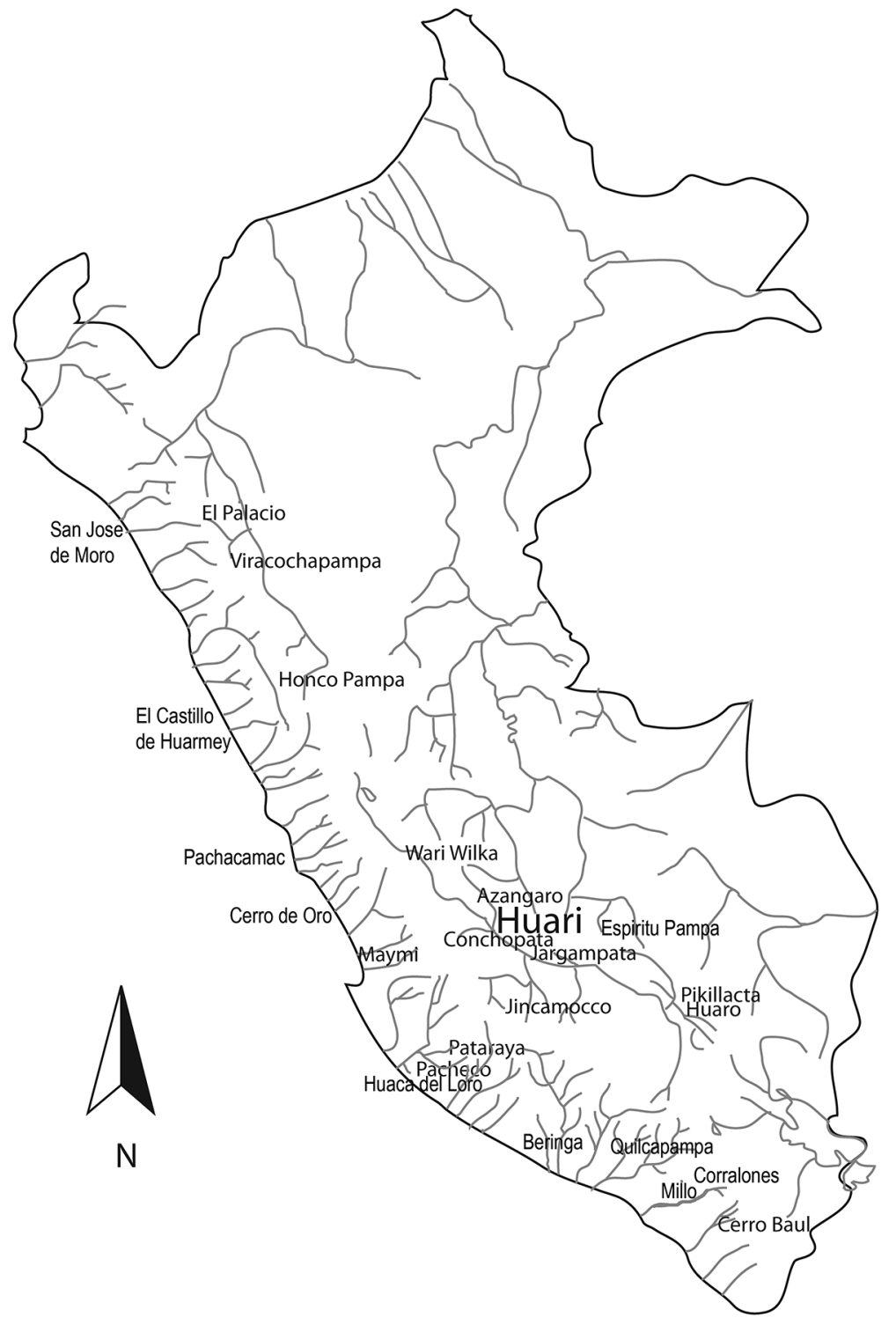

Figure 1. Wari settlements and sites with Wari material culture in Peru.

mined by the value and uses of decorated Wari pottery as they relate to statecraft and imperial expansion. To address these issues, I review models of craft specialization and the presumptions regarding relations of production for prestige goods. I also examine how the use and value of a good may impact its distribution. To contextualize this study, I will first outline the ideas of previous researchers who have linked the production of Wari decorated pottery to the polity's political economy. 


\section{MODELS OF WARI CRAFT PRODUCTION}

The Wari Empire was an expansive Andean polity that preceded the Inka. For that reason, models of the Wari political economy are largely based on Inka ethnohistory in terms of the "Inka Mode of Production" (Godelier 1977). From this perspective, the Wari state collected taxes as labor, and workers were fed from state stores during their service (Isbell 1991). This reciprocal exchange fueled agricultural expansion and monumental constructions. It also supported elites and generated wealth. In this model, local leaders also attended feasts accompanied by much chicha (corn beer) and were placated with gifts of various types. These long-held ideas are applied to interpret the archaeological record, but as research progresses several clear differences have come to light between the Wari Empire and this model of the Inka, which is based on ethnohistory, and not necessarily borne out by the archaeology.

Some Wari contexts have archaeological remains commensurate with feasting. These are small venues and likely represent intra-elite events (Nash 2012a). It has been presumed that the gifting or exchange of preciosities was significant to the Wari political economy because of the high quality of many Wari-affiliated goods (Earle and Jennings 2012). Although the gifting of prestige goods may have been an elite strategy, the distributional data needed to support this model are not currently available for most regions. Nevertheless, models emphasizing elite control of production for exchange are prominent in explanations of the Wari political economy.

For instance, Lumbreras (1990) postulated that the urban center of Wari (Huari) represented a shift away from theocratic leadership such as that represented by Chavin de Huantar, which relied on theatrical ritual performances in monumental settings. Instead, the emerging city was a new civil form that was organized around the production of goods by specialists where elites derived power from managing resources and production. In this vein, Pozzi-Escot et al. (1993) interpreted Conchopata, a large site $10 \mathrm{~km}$ from Wari, as a community of potters. Their products were an essential element of the capital's economy that were exchanged with groups living in other zones. As the state grew, the production of ceremonial goods moved to the capital city itself, while domestic items continued to be produced at Conchopata.

The evidence from Conchopata was interpreted differently by Isbell and Cook (1987), who maintained that ideology played a role in the emergence of the state because many of the vessels at Conchopata depicted group scenes that reified hierarchical relations. They viewed this iconography, which appeared at both Wari and Tiwanaku, as an ideological innovation that legitimized social difference and state authority. Initially, Isbell and Cook cast artisans as attached specialists collaborating with innovative priests, but Cook (2004) now considers the potters to be wealthy elites because of their access to gold and silver items. Artisans' residences each had their own production facilities (Cook and Benco 2000) and monumental tombs with ceramic vessels of a quality attributed to high-status members of Wari society (Cook 2004).

Alternatively, Isbell (2007) identifies ceramic producers as female members of polygynous elite households. He proposes that women of different ranks made chicha, 
feast foods, and fine ceramics as part of a "feasting complex," which emerged with palatial residence at Conchopata to enhance the prestige of the site's governor. Isbell interprets the dispersed pottery production tools and features as the remains of three temporally distinct palaces and the appended housing of courtiers. Cook's model suggests elite craft production is one aspect of elite competition at the site, whereas Isbell interprets the production localities as a set of sequential facilities focused on competition with elites from other centers.

A third interpretation comes from Ochatoma (2007), who proposes that the spatial arrangement of production represents a dual model of production. He suggests that small whistles, figurines, and ceramics consumed in domestic settings were made in households, while ceremonial pottery for rituals was made in public areas such as the "pink plaza" (see Ochatoma 2007:170). Wolff (2012) has recently examined the ceramic production tools and related materials from the site and concurs with Ochatoma. This interpretation raises an important point. It is quite possible that different types of pottery were made and distributed in distinct ways. ${ }^{2}$

These interpretations of production at Conchopata were recently called into question as a result of Tschauner and Isbell's (2012) GIS analysis of artifact distribution patterns. They compared concentrations of materials such as lithic debris and botanical remains with areas having high frequencies of ceramic production tools and concluded that some of these spaces represent garbage deposits rather than production areas. Although a full reinterpretation of the data from Conchopata is beyond the scope of this paper, my examination of the published excavation data suggests that the location of features such as kilns maintains the validity of Cook and Benco's (2000) proposition that some ceramics were produced in elite residences at Conchopata. ${ }^{3}$

Evidence of Wari pottery production has also been found at Maymi, a coastal site in the Pisco Valley, where crafting debris extends over an area of 5,000 $\mathrm{m}^{2}$. Excavation revealed three pit kilns and associated activity areas for clay preparation, vessel shaping, painting, drying, and storing finished vessels. Offerings and food were found near production debris, but more excavation and study is needed to understand the context of production (Anders et al. 1998). Also, in an empire such as Wari, which conquered many groups that already had their own effective political economies, we should not expect all provincial elites to employ the same empowering strategies or for similar objects to involve the same technologies and relations of production (e.g., Buxeda and Tuset 2010). It is quite possible that attached specialists made ceremonial pottery in some Wari provinces.

\section{CRAFT SPECIALIZATION AND ELITE STRATEGIES}

Crafting is essential to daily life and technically goes back to the earliest stone tools (Costin 1998). Craft specialization as defined in the archaeological literature is different and refers to the production of items for use by people outside the household (Costin 1991; Inomata 2001). The term may bring to mind artisans who produce special things, but judgments on quality cannot be used to make this assessment. High-quality products 
may result when all households produce an item, such as the decorated vessels of the American Southwest (ca. 500-1150 CE) that were used on a daily basis and produced by most if not all households (Crown 2001). Relative skill, the time devoted to learning the production process, and the quality of the finished product are not a part of the traditional definition of craft specialization (this is not to say they should not be). Instead, researchers have focused on interactions with consumers outside the household.

This emphasis ignores the fact that most households are not truly self-sufficient. Some percentage of a household's production, whether it be foodstuffs or artifacts, goes to exchanges with neighbors to maintain sociality or is offered to a supernatural in fulfillment of a perceived obligation (Mayer 2002; Sahlins 1972). This small-scale overproduction may not fit with notions of craft specialization; however, some forms of overproduction do. Overproduction refers to extra production of a good that all households should ideally make to supplement or enhance the household's economy. This would be very difficult to detect archaeologically unless household overproduction attains sufficient scale or prominence that it leaves production debris in quantities substantially above those in other households.

Intensive production in domestic settings is easy to detect. It is quite common among New World societies (e.g., Feinman and Nicholas 2007; Hirth 2009; Janusek 1999). In contrast, a sizable sample of excavated houses is needed to enable researchers to recognize the special tools, uncharacteristic production debris, or multipurpose production zones diagnostic of small-scale, residential crafting. Archaeologists are often conservative in their identifications of craft specialization when it is situated in the domestic sphere (Feinman and Nicholas 2004:173) and require overwhelming evidence, such as mounds of production debris or specialized craft areas within the residence. This convention downplays the prevalence of small-scale or part-time domestic craft specialization and ignores the importance of household overproduction, which can provide a significant supplement to the household economy (Nelson et al. 2002).

Furthermore, the term "specialization" has been selectively applied based on gender. Elite women in the Inka era made fine textiles of high value in residential contexts. These were worn as insignia by members of the household, given as gifts to other elite groups, or burnt as offerings. This instance of overproduction was essential to the political economy, but since Inka ideals as translated by Spanish chroniclers attributed textile production to women of all ranks, the activities of elite women making fine, valuable cloth in palaces are not discussed as craft specialists by archaeologists-but male textile specialists who also presumably crafted in their dwellings are (Costin 1998). Somewhat fittingly, archaeologists would have no way of discerning the difference. Instead, the scale of production would need to meet a particular threshold since the traditional definition of craft specialization emphasizes exchange.

\section{Types of Specialists}

Many archaeologists think about craft specialization as an either/or proposition. Most follow the typology established by Brumfiel and Earle (1987), which contrasts the 
attributes of independent producers with those of attached specialists. "Independent specialists" are those who "produce goods or services for an unspecified demand crowd" and make decisions based on "efficiency and security" (Brumfiel and Earle 1987:5). Even under conditions of sufficient demand and stable accessibility to food through exchange, many independent specialists continue their subsistence activities while they craft part-time. Alternatively, "attached specialists are contractually bound to the patrons for whom they work, and frequently, the patrons insure that all the specialists' basic needs are met," which sustains "full-time specialization" (Brumfiel and Earle 1987:5). Attached specialists are also concerned with efficiency and security; however, this form of specialization develops because of the elite desire to control the production of certain goods and ultimately the political economy.

These definitions are based on the underlying assumption that the value of goods and the reason for their production come from the need or desire to engage in exchange; however, this may not always be the case. Some objects, such as royal insignia or religious paraphernalia, are made exclusively for display by a limited number of consumers (Gluckman 1983; Kopytoff 1986). These alternative sources of an item's value may engender different relations of production. In such cases the distribution patterns of particular goods may help determine the source of their value. Items deployed to build relations and those exclusively displayed by a kin group may be equally empowering, but these items would have different patterns of distribution. Elites may pursue both strategies with different goods to garner power.

For example, both exchange and display were power-building strategies on the Northwest Coast of North America during the eighteenth and nineteenth centuries. These well-documented groups were organized into large, multi-class suprahouseholds which formed ties through marriage and potlatch activity in the absence of fixed hierarchies. According to Ames, these societies had "embedded specialists" that were "full or part-time specialists whose vocation is part of the household or local economy, and the specialist's activity is integral to that economy." Also, their "performance is part of the individual's social role defined not on a purely economic or class basis, but on a kinship basis" (Ames 1995:158).

Among the Tsimshian, some chiefs were specialists, and an exclusive group of councilors, the gitsonkt, used secret techniques to make masks and mechanical devices for ritual performances. Ames's (1995) example resembles discussions of elite artisans among Classic Maya polities, but Inomata (2001) explains the difference. Ames's notion of embedded craft specialization is at the "macro scale" because it describes the relations of production for the entire community and a wide array of goods rather than highlighting a particular type associated with prestige goods or elite production. In other words, when production is organized as embedded craft specialization, there may still be a distinction between independent and attached specialists.

Janusek's description of embedded specialists at Tiwanaku (600-1200 CE) illustrates this point. He contends that the skilled crafting of most valuables would have taken place in the context of ayllu (suprahousehold groups of various scales), which 
were "controlled by local authorities who ultimately answered to state rulers" (Janusek 1999:125). Given this framework, he proposes that attached specialists may have produced the "highly standardized and elaborate vessels that were found to be ritually consumed" (i.e., smashed as offerings) on the Akapana (Janusek 1999:124), while these same specialists may have had opportunities during "major social events and calendrical ceremonies" to "promote their wares and exchange them for necessary or desired goods" (Janusek 1999:126). These fluid relations of production parallel some of Ames's (1995) examples, in which specialists may temporarily serve as attached specialists and at other times produce preciosities for their own group.

Both Janusek and Ames provide examples of embedded specialists crafting goods with ritual value. Yet, Ames's concept of embedded specialists puts all producers in the same category and does not distinguish between the producers of utilitarian and prestige goods. I suggest that current definitions do not permit us to think about and discuss elite specialists who produce objects that empower their kin group through display, the fabrication of ritual paraphernalia, or "overproduce" high-value items to engage in relatively exclusive exchange relations or gifting. It would seem that to include this important elite strategy in archaeological discourses of the political economy, the definition of specialization may need some refinement.

Inomata (2001) has also raised this issue with evidence for elite crafting at the Maya site of Aguateca. For the Maya, the act of creating some objects exuded power, and the requisite esoteric knowledge to perform some crafting activities could only be obtained by a member of the elite class (McAnany 1993). Inomata (2007) interprets the design of some elite residences as performance spaces, where crafting could be viewed. Since some Maya gods were depicted as crafting objects, elites may have created contexts in which they could demonstrate they shared this supernatural ability with the gods (Reents-Budet 1998). Of course, elites as artisans may have purposely depicted gods as craft specialists to claim this divine affinity. In either case, such displays may have been one source of power for elite craft specialists.

Inomata explains that elite craft specialization cannot always be identified as representing attached or independent production since elites often craft for their own political ends and their products are not made for the market. Elite artisans have other sources of support and are not concerned with efficiency or security. His discussion reveals the limitations of current categories; producers who are not dependent on crafting may make valuables as a strategic means to garner power. He also makes a strong argument about the ideological context of production. It would seem that the act of crafting itself was empowering in addition to the value of the finished product (see also Carter 2004). This issue may also be relevant to examples from the Andes, where some items may have been considered animate, which might make their production an empowering strategy.

\section{Crafting in the Andes}

Western ontology distinguishes between people and things, but this was a blurry line in the early colonial Andes (Salomon 1998). Some highland Andean communities 
continue to imbue the earth, mountains, and other landscape features with animate powers. Chthonic forces are believed to control water, weather, fertility, and mineral resources and are venerated with performances and offerings that maintain an ongoing reciprocal relationship (Allen 1988; Gose 1986). Researchers have shown that similar practices date back to Wari times (Leoni 2006; Schreiber 2005; Williams and Nash 2006, 2016).

Some crafted objects were regarded as animate. Considering ethnohistoric sources, Bray explains that the concept of camay "carries the connotation of bringing something extant into being through the energizing of existing matter (as opposed to creating something from nothing)," and that "camay intends something of continuity in sustaining the being, a condition that involves an on-going relationship between the camac (e.g., the 'camay-er') and its camasca (e.g., its tangible instantiation)" (2009:358-59). This idea is expressed in the Huarochiri Manuscript (Salomon and Urioste 1991) in which two different Quechua verbs for "to be" were used to represent distinct types of existence. Salomon explains that the huaca (sacred thing/entity) "Chaupi Namca 'was,' 'acted' (carcan) in a past-tense form, because prior to the time of writing Christians had already desecrated and ritually deactivated her, but she 'is' at the time of writing still 'situated' (tian), because her stone embodiment 'is' still hidden where she was buried" (1998:8). Presumably, ritual veneration might reactivate her.

The concept of camay could have implications for the status of craft specialists known as camayoq. They had the capacity to transform matter and potentially bring huaca into being. Further, the crafting of some objects may be considered an ongoing process. Production may not be an isolated event but a reciprocal relationship between the maker and the made object. The power to make and maintain is generated through performance and offerings. A sacred object is "fed" and venerated to energize its animate qualities and benefit the group (Allen 1988).

Thus, producing sacred items, such as decorated vessels, may have been an effective elite strategy. Such vessels may have been more than symbols representing supernatural forces. They may have been energized with their own power. Ritual items would remain active through use (pouring libations, toasting, drinking) but may become inactive through neglect or ritual decommission, such as smashing. We cannot be sure if vessels were considered animate during Wari times, but if they were, artisans may have held special status. Ideas about a type of object and its intended use may have influenced or determined the identity of its producer.

\section{The Strategic Use of Things}

As a gift, any item can be engaged to build social relations between people or groups. Since Mauss's (1990) famous treatise on the gift, anthropologists have recognized the potential objects have for establishing temporary social asymmetries or maintaining sharp power differentials (Godelier 1999). Sahlins explains that, "Generosity is a manifest imposition of debt. ... [T] he economic relation of giver-receiver is the political relation of leader-follower" (1972:133). Generosity in the form of gifts or feasts may 
be manipulated to achieve status and power through indebting followers (Rehfisch 1987). Gifting and "regifting" the same item is also a salient way to create equitable bonds (Godelier 1999).

Popular models of craft specialization and elite control of production are predicated on the presumption that goods are made for exchange or gifting. Yet, Ames's and Inomata's examples show that other factors may have been important. The masks Ames describes were for ritual performances. They were not intended to circulate. Instead, as singular objects they were kept outside spheres of exchange and they would not be distributed as gifts. This phenomenon is referred to as "singularization," and it is an expression of symbolic power. According to Kopytoff, rulers who reserve certain items for their exclusive use "expand the visible reach of sacred power by projecting it onto additional sacralized objects" (1986:73). The "paraphernalia of political power," "chiefly insignia," or "ritual objects" rarely enter the commodity sphere of exchange and "are not merely 'symbols' of something more 'concrete,' such as power; they are valued goals in their own right, a part of 'power' rather than a representation of it" (Kopytoff 1999:93). The fact that many chiefdoms and states imposed sumptuary laws suggests that elite investment in craft specialization may often have more to do with power and politics than exchange and economics (Peregrine 1991; Schortman and Urban 2004).

Spielmann's (1998) research, which suggests a link between the source of an object's power and the identity of its maker, supports this connection. She observes three patterns for crafting ritual goods in middle-range societies. First, independent specialists or nonspecialists produce ritual objects when ritual is not an exclusive form of power. Second, attached specialists or embedded specialists will produce powerful objects for competitive displays or ritual performances, "where ritual knowledge and performance are one of several means of achieving and maintaining status" (Spielmann 1998:158). In such circumstances, the performer may also be the artisan. And third, in cases where ceremonial knowledge and ritual performance are crucial aspects of obtaining and maintaining status, Spielmann predicts that the practitioner will also craft the necessary sacred objects as a means of excluding others from these empowering activities. The patterns described by Spielmann suggest that the source of an object's value may determine the identity of its producer and its role in power relations. The cases discussed thus far suggest that crafting may empower those seeking prestige or legitimize their elite status in a number of ways. The meaning of an object and the context in which it is used are crucial aspects of its role in the political economy and may influence the identity of its producers.

\section{ELITE STRATEGIES AT CERRO BAÚL}

Cerro Baúl was built on an impressive mesa, which towers $600 \mathrm{~m}$ above the Torata tributary of the Osmore River in Moquegua (Figure 2). The Wari provincial center encompasses roughly 15 ha. The eastern area of the mesa is densely covered by high-walled compounds. Dense rubble, the remains of multistory stone masonry buildings, make 


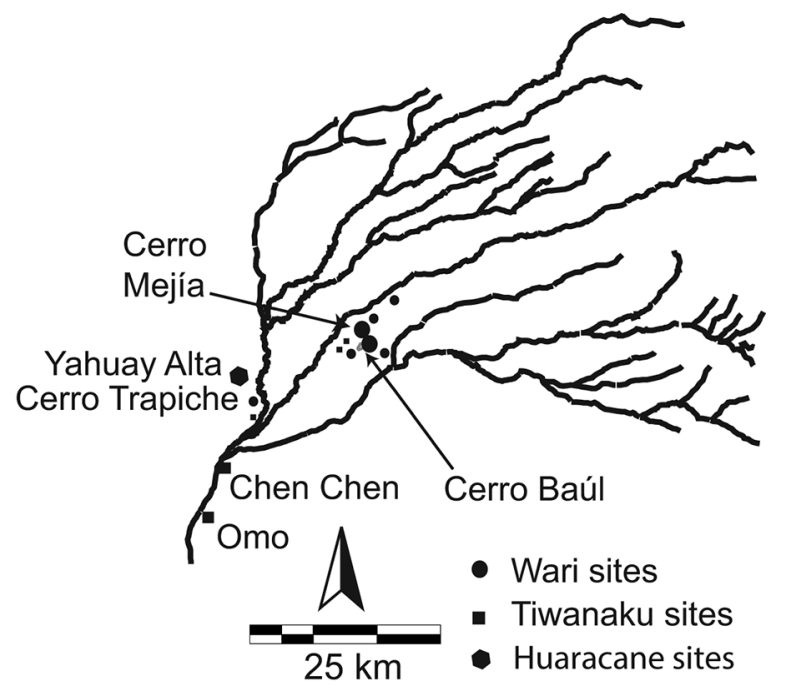

Figure 2. Middle Horizon sites in the Moquegua Valley.

it difficult to ascertain the exact architectural plan. Aerial photographs reveal a few broad corridors cutting through the complex, and these were used to divide the site into sectors. Cerro Baúl has two D-shaped temples (sectors B and C), a mound and platform complex (sector E), and a ritual precinct dedicated to Tiwanaku-affiliated practices (sector D; Williams and Nash 2016). Several buildings in sector $C$ are attributed to storage and administration. A large-scale brewery for the preparation of chicha is located in sector $\mathrm{B}$, and a palace is located in sector A (Figure 3).

Elite artisans made pottery in the Baúl palace, a large, elaborate residence with flagstone floors and painted, plastered walls. All palace spaces exhibit some form of ritual abandonment, which appears to overlay de facto refuse from daily activities. Dense deposits of smashed pottery were recovered from the forecourt (Unit 25) and patio group (Unit 9). Such offerings are clustered in the doorways of the ceramic workshop (Unit 40A) and garden (Unit 40C) or as dispersed concentrations in the other areas. This pattern of ritual abandonment is also prevalent at Conchopata and complicates using the placement of tools to identify work areas. In both cases, features are more reliable indicators of activity areas (see Nash 2010).

The elite residence on Cerro Baúl is a large compound of approximately $2060 \mathrm{~m}^{2}$ (Nash 2012a). Its central roomblock replicates the spatial organization of buildings at the Wari capital in Ayacucho, Peru, and Wari-affiliated sites in other regions. Previous scholarship suggests that these structures, called Wari patio groups, were associated with administration and feasting (Isbell 1989; Isbell et al. 1991). If so, then these residential structures were settings for religious and political activities or institutionalized practices along with temples and public ceremonial spaces (Nash and Williams 2005). The elaborate vessels smashed as offerings exhibit extensive evidence 


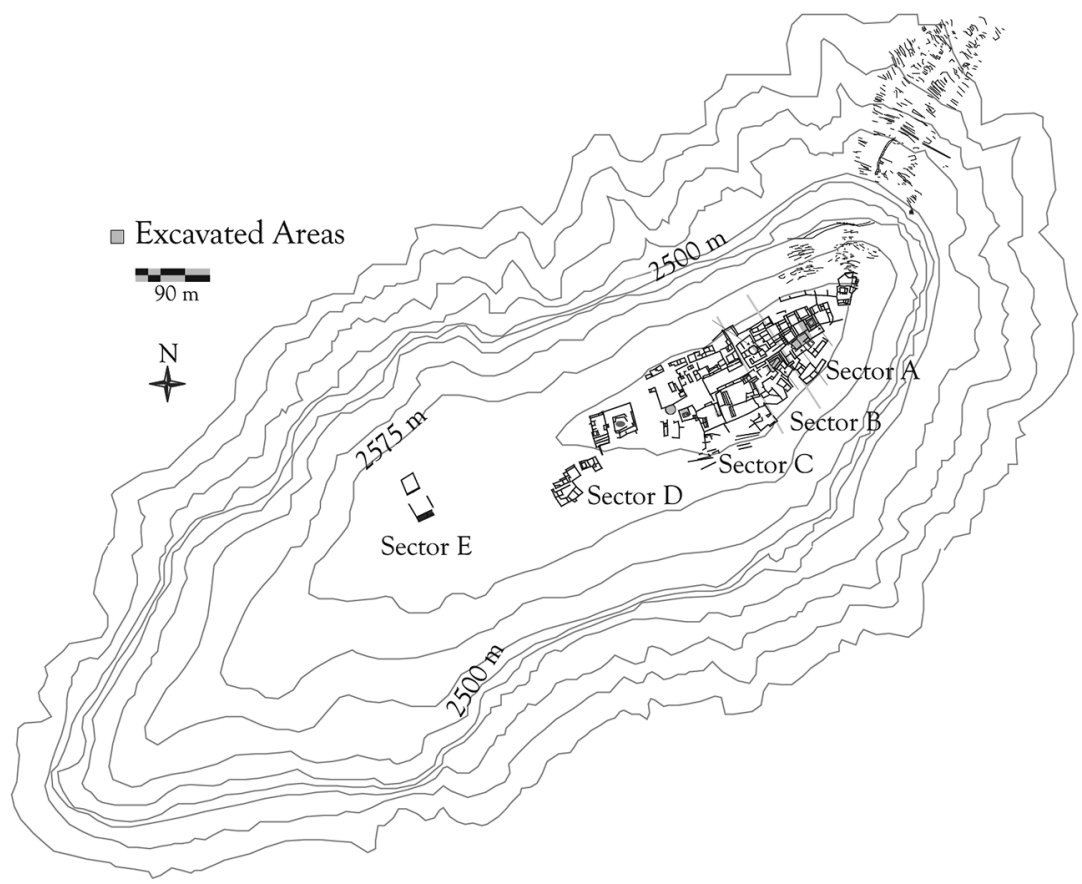

Figure 3. The provincial center of Cerro Baúl.

of use and may correspond to decommissioned sacred paraphernalia deposited during the palace's abandonment. I consider the elite residence in sector A of Cerro Baúl a palace, even though it does not represent the dwelling of a sovereign, for three reasons: (1) It incorporates features of Andean palaces from later periods (see Pillsbury and Leonard 2004); (2) its design clearly incorporates spaces to facilitate sociopolitical gatherings (Christie 2006); and (3) it appears to have been the paramount residence in the Wari province of Moquegua during the period of its occupation (see Nash 2010, 2012b).

I selected this compound for study because I wanted to examine the role of feasting in the Wari political economy. It was presumed that feasting would take place in the houses of leaders participating at some level in the empire's political hierarchy and be absent from the dwellings of commoners (Isbell 1991). To test this idea, I selected a representative sample of houses based on their size and elaboration from the adjacent sites of Cerro Baúl and Cerro Mejía. The sector A palace was the most elaborate dwelling in the sample. I expected it would exhibit evidence of feasting, have the most prestige goods, and the largest storage capacity. I further hypothesized that features associated with leadership might appear at a smaller scale in the largest summit-top dwellings at Cerro Mejía (Nash 2002, 2010, 2012b; Nash and Williams 2009).

These expectations aligned with prominent models that proposed elites could host feasts to enlist support or build power, while also controlling the production of craft 
specialists in order to monopolize preciosities for display, distribution, or exchange (e.g., D'Altroy and Earle 1985). Some of my expectations were borne out by excavations; I did find materials associated with feasting. It was a strategy employed by elites on Cerro Baúl and Cerro Mejia. Yet, I also found indications that decorated pottery, a presumed prestige item (based on its rarity and affiliation), was produced by elite members of the palace household rather than attached specialists in a palace annex. In addition, decorated Wari pottery was not present in the houses of elite subordinates - it was not distributed as a prestige good to endear clients. These findings have implications for understanding the political economy of the early Wari state and the diversity of strategies employed by would-be leaders in ancient polities (Nash and Williams 2009).

\section{Evidence of Elite Potters at Cerro Baúl}

The evidence of ceramic production at Cerro Baúl is different from that at Conchopata and Maymi. The loci of ceramic production are not spread across the site. The frequency of production tools is relatively low; no one would suggest Cerro Baúl was a community of potters. The vessels found in the palace are not as elaborate as the finest examples found in offerings at Conchopata and Maymi; however, there are fine vessels elsewhere on Cerro Baúl, and both Conchopata and Maymi have a range of vessel types of different qualities. Finally, Conchopata has large vessels decorated with mythical scenes that were presumably made by artisans at the site. At Cerro Baúl the current assemblage is limited to smaller decorated vessels. One might presume these portable pots were brought in from elsewhere, but LA-ICP-MS shows that the majority of these vessels were made with local materials (Williams et al. 2019). Large, finely finished vessels have been found at Cerro Baúl, but they do not have elaborate iconography.

The primary occupants had access to large quantities of obsidian, metal objects, and decorated pottery relative to other households in the Wari colony (Nash 2012b). As I describe below, features and tools related to ceramic production are located in several parts of the residence. The placement of features throughout the palace suggests that artisans were elites with free access to all spaces rather than attached subordinates relegated to a palace annex or small, cramped work quarters in the rear of the building.

The sector A palace (Figure 4) resembles later Andean palaces in its general design. The entrance has not been excavated but appears to be a turning, narrow passage. The corridor opens onto a forecourt (Unit 25) with benches along the walls and a recessed niche at bench level in the southwest. This niche may have been used for presiding over gatherings in the forecourt (Nash and Williams 2009). The adjacent plaza to the northeast (Unit 40A) has numerous features related to the preparation of clay and temper (Figure 5). The floor has many pit features, which contained raw clay, chunks of temper, or balls of unfired paste. One feature may represent a levigation tank, a technology presumed to have been in use by Wari artisans based on the small size of inclusions observed among Wari pastes (Castillo et al. 2012). Desiccated wooden beams found along the northeastern wall are likely the remnants of an awning that once shaded 

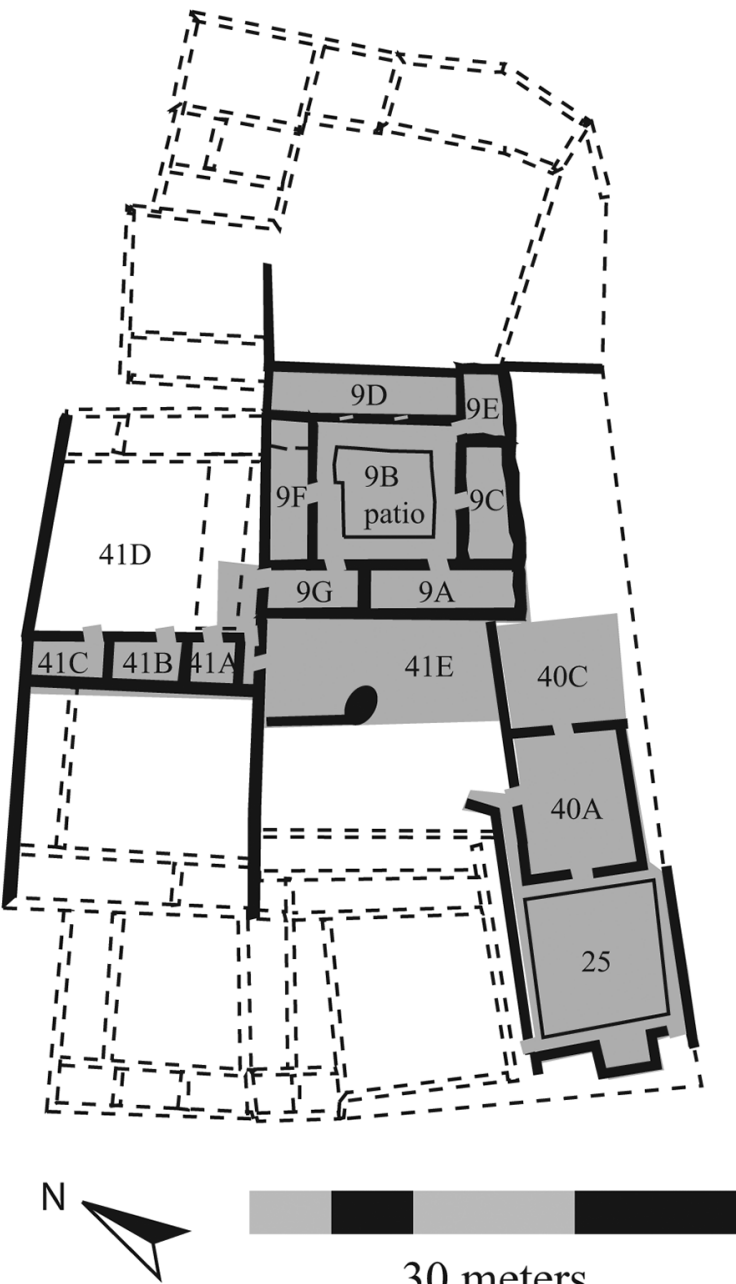

\section{0 meters}

\section{Previous excavations}

$\varepsilon=$ Wall based on surface observation Hypothesized wall location

\section{Wall observed during excavations}

Figure 4. The sector A palace on Cerro Baúl.

the levigation feature. A large grind-stone covered with percussion marks from pulverizing clay and temper was found, but its orientation suggests it was not found in situ.

To the northwest another plaza (41E) had other features, including an area for grinding a yellowish gold micaceous temper and three small storage pits that con- 


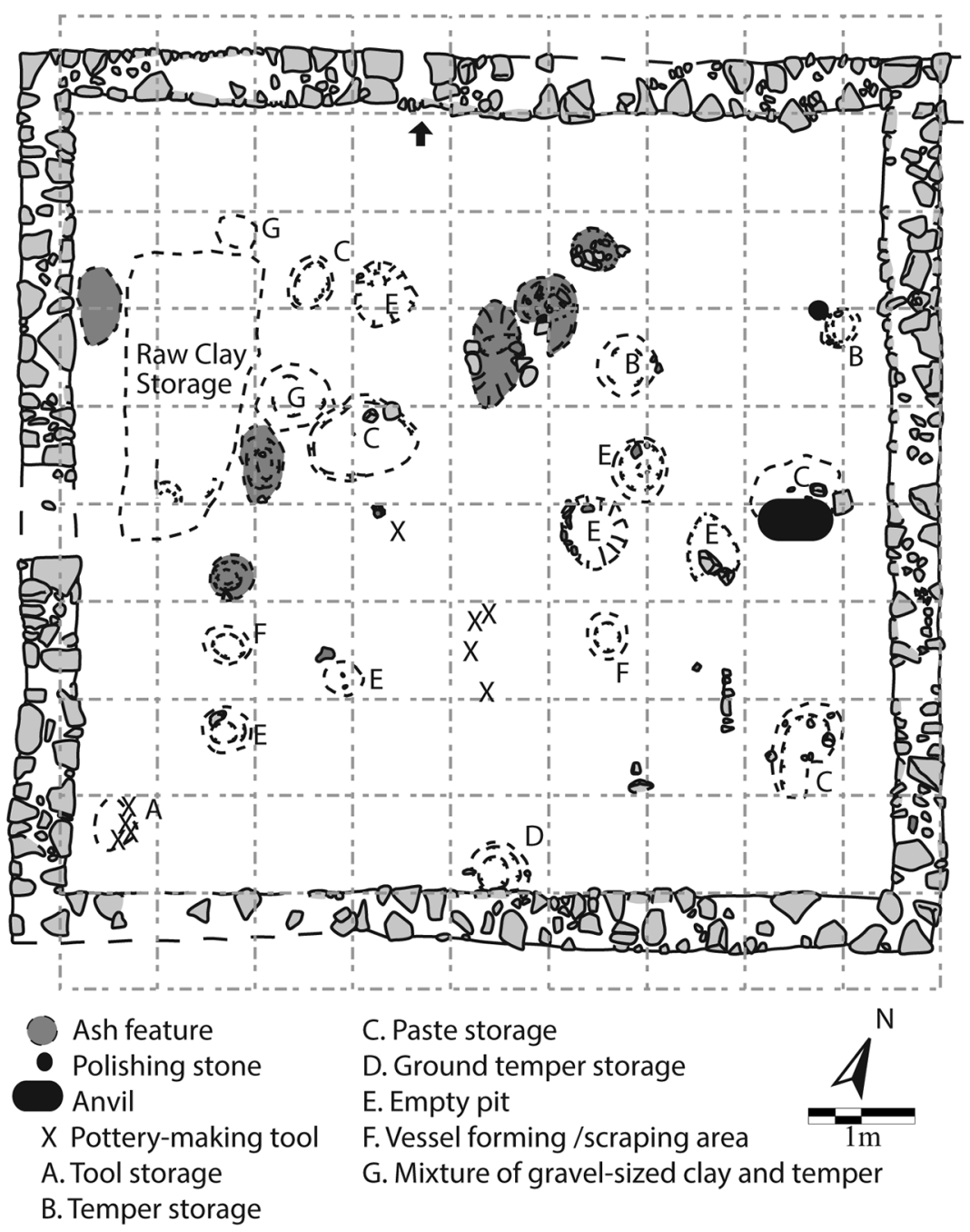

Figure 5. Unit 40A with ceramic production features.

tained powdered minerals of different hues and are presumed to be slip pigments. A garden to the northeast (40C) was used to store blocks of temper (volcanic tuff). There was also a pit feature that contained what might be compressed "briquettes" of camelid dung. These may have been used as fuel for firing the vessels, but they could also have been used for cooking.

To the north on a lower platform is a roomblock consisting of a multilevel patio (41D) and three domestic rooms, each situated on a different terrace (41A-C). The patio (41D) also connects with the Wari-style patio group (9). It has a central patio (9B) bordered by five rooms (9A, 9C, 9E-G) and an elevated platform (9D). The patio 
has benches on all sides and could be entered through Room G. Rooms A, C, F, and G exhibit evidence of domestic activity. Room $\mathrm{E}$ and the platform (9D) were disturbed by Inka offerings (Figure 4). The most compelling evidence that elites were producing pottery was a feature in the elite residential patio group. In Room 9A an unfired vessel was found in a pit. Presumably the pit supported the steep sides of the vessel during drying. Unfortunately, the form of the rim could not be determined, but the vessel had handles midway down the vessel body on both sides. The thickness of the vessel $(0.3125 \mathrm{~cm})$ is consistent with finely finished serving wares and does not correspond to the more rustic storage jars, which have notably thicker vessel walls and handles near the rim.

Tools may have been ritually dispersed, but other materials related to production appear to have been left in situ. For example, in $41 \mathrm{C}$, an ash feature, probably used to hold garbage temporarily, contained partially fired clay clumps. Fragments of misfired and unfired pottery were also found in 40C and 41E. Large chunks of pinkish volcanic tuff (used as temper) were found in $40 \mathrm{C}$. This material also appears to have been used at Conchopata and gives the "pink plaza" its name. Wolff (2012:126) refers to volcanic tuff as pozzalana, which is currently mined to make bricks and cement in Ayacucho. Volcanic tuff is not mined for large-scale industry in Moquegua as it is in Ayacucho. The pink volcanic tuff outcrops on the summit and flanks of Cerro Baúl. It is also visible in road cuts throughout the adjacent river drainages.

Tools from Conchopata (Wolff 2012) and Maymi (Anders et al. 1998) resemble those from Cerro Baúl, which are mostly recycled potsherds (Figure 6); however, Conchopata also has ceramic tools made specifically for pottery production (Wolff 2012). Worn sherds from Cerro Baúl exhibit a variety of shapes for scraping, burnishing, and smoothing vessel surfaces. Some examples have very smooth edges, which corresponds to what Wolff (2012:157) calls "potters' ribs." Other tools have rougher edges and exhibit specific shapes that mirror the inflection points or vessel contours (Figure 6). Potting plates were made from broken vessel bases or large, nearly flat sherds (Figure 6). These slow wheels have visible abrasion consistent with rotation and were presumably used to turn a vessel during manual shaping, surface finishing, and decoration. Ovoid stones were also used to polish vessels. A few still have tinted clay embedded in their micropores, presumably from polishing slipped vessel surfaces.

Many misfired or unfired fragments have been found in different areas of the palace. This sample includes sherds of different thicknesses. Some examples have very fine, compact pastes with no visible inclusions, whereas others have large pieces of quartz and other inclusions. The former attributes correspond to fine serving wares and the latter pertain to storage and cooking jars. Several types of pottery were probably made in the palace workshop.

\section{Alternative Explanations for Elite Crafting}

There is strong evidence for pottery production in the sector A palace on Cerro Baúl. Although elite crafting of pottery in a state-level society does not conform to tradi- 


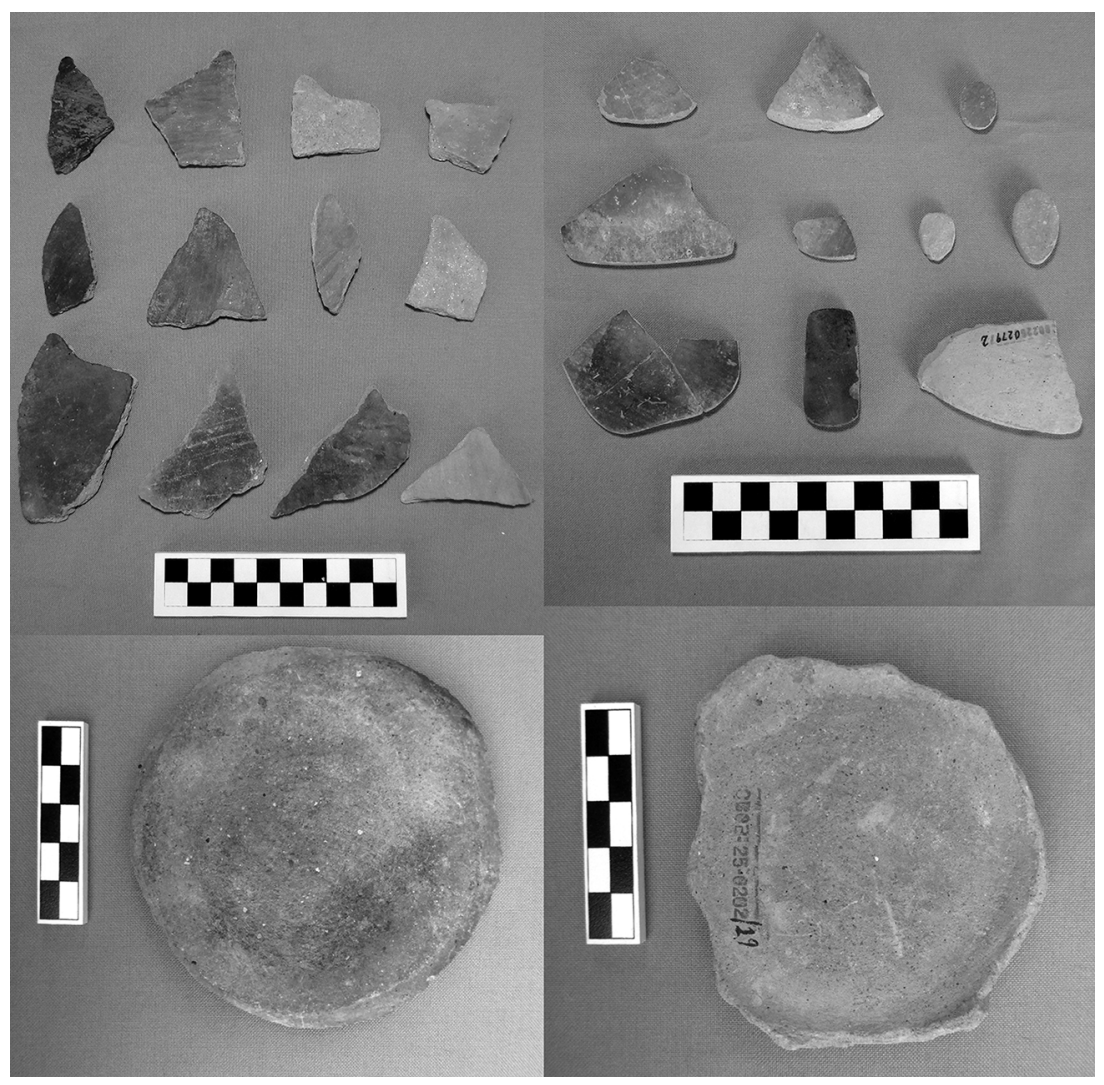

Figure 6. Ceramic production tools made from recycled sherds and two potter's plates found in the palace.

tional expectations, there are scenarios that could explain elite craft production on Cerro Baúl. Pottery production may have been a domestic activity practiced by most households in Wari society. It is also possible that the location of Cerro Baúl on the Wari frontier, more than $500 \mathrm{~km}$ south of the capital, may have limited elite access to resources and labor, which meant they had no choice but to make decorated vessels for feasts and rituals. Alternatively, crafting vessels for feasting, ritual performances, or as offering inclusions may have been an empowering activity. Elites could exclude others from producing and distributing these salient goods by monopolizing the knowledge and resources to make decorated pottery.

Pottery Production as Domestic Activity? Since ceramic production at Conchopata appears to have been widespread, and Cerro Baúl also has domestic production of pottery, it is reasonable to ask if ceramic production is part of typical domestic activity, especially if quotidian wares were made side-by-side with fine serving vessels. Perhaps all households made pottery for their own use. This may have included fine 
vessels intended as gifts in the case of elites. In the Wari Empire, few studies have focused on quotidian goods (cf. Bencic 2000; Owen 2007); however, specialization has been found among households in Moquegua (Nash 2010, 2012b).

At Cerro Mejía, a large settlement near the provincial center of Cerro Baúl, more than eighty terrace dwellings are spread across six walled barrios on the hill's southeastern slope. The sample of excavated houses in this sector is just over $10 \%$, and a few have evidence of craft production. One residence had a high concentration of obsidian debitage consistent with shaping points and knives, but all houses have obsidian debris resulting from retouch or sharpening. Two houses also had unfinished points made of white chert, which comes from an outcrop $50 \mathrm{~km}$ down-valley. A small concentration of unfinished spindle whorls (made from sherds) may also represent specialized production.

On Cerro Mejía no house has a courtyard dedicated to ceramic production such as that found in the Baúl palace. The scale of production is much smaller. On the terraced slopes of Mejia, ceramic production took place among other domestic activities in two houses, which were in different barrios. On the summit of Cerro Mejía, where houses are much larger, I found a potter's plate and worn sherds in one elite residence, but not in the other excavated compounds (Nash 2002, 2012b; Nash and Barrionuevo 2008).

The production of goods may have been a part-time specialization in some households at Cerro Mejia, and only obsidian biface reduction required a separate work space. Points of obsidian or chert, spindle whorls, and pottery were not made by every household, although finished examples of these goods were evenly distributed throughout the community. Ceramic production was not a domestic activity common to all households on Cerro Mejía. It was a specialization in the Wari province of Moquegua.

Elite Production of Pottery as a Necessity in a Frontier Context? Ceramic production in the palace on Cerro Baúl may be unusual because of its distance from the Wari capital. Perhaps elite colonists had to be more creative in this region because of limited resources or a tenuous command on labor. Elites may have led a less comfortable lifestyle with insufficient resources to support attached specialists. The limitations of the frontier may explain why elites were making pottery. This scenario was proposed by a reviewer, and it is a valid question, but a brief review of data from this region does not accord with this possibility.

Cerro Baúl, on its lofty mesa, is an impractical settlement with no direct access to water. To support life at the provincial center, the agricultural system required the construction of an extensive canal system and the transformation of the steep landscape into majestic staircases (Williams 2006). All essentials had to be carried up to the mountain-top citadel. Tons of water were needed to mix the mortar for walls and the plaster to surface them. Tall trees were needed for roof rafters; examples exceeding $10 \mathrm{~m}$ were found preserved as part of a collapsed second-story floor. The summit also had a large brewery with the capacity to make approximately 1800 liters of corn and molle chicha in a single batch. Those living in the sector A palace had access to a 
rich and varied diet, which included ocean fish, a rare resource brought more than $90 \mathrm{~km}$ from the coast (deFrance 2014). The structure itself and the other materials of value found inside represent great social differences between palace dwellers and commoners (Nash 2012b). I could describe many other features if space permitted, but in short, the Wari occupation on Cerro Baúl was an exercise in conspicuous consumption. The elite at the site were not short on labor or resources.

Remains associated with pottery production, weaving, lapidary work, and biface production were found in the palace; however, intensive crafting also took place immediately outside the palace and presumably were the work of attached specialists. I collected a large quantity of semiprecious stone (sodalite, chrysacolla, and onyx) on a terrace below and to the north of the palace. ${ }^{4}$ The blue stone recovered ranges in quality from low to high, whereas unfinished items in the palace are all high quality. ${ }^{5}$ Primary reduction of raw materials may have taken place outside the palace, and the finest pieces were then worked by elites in the palace. An obsidian workshop was also located on a lower terrace south of the palace. We have not found an area for the preliminary processing of clay outside the palace, and given that large chunks of temper and areas for processing clay were found in the palace, it is unlikely that stages of processing were carried out by different personnel; however, subordinates may have been charged with the mining of raw materials and their transport to the palace.

Pottery Production as Elite Strategy? The elite family living in the sector A palace had access to labor for craft production but chose to make pottery. Pottery was produced in at least three households on Cerro Mejía. Theoretically, these artisans could have been commissioned to make pottery for the palace. Yet, it appears that the production of fine, decorated pottery was exclusive. For instance, there are no indications that "knock-offs" of Wari vessels were made for consumption by the lower classes. In fact, very few vessels on Cerro Mejía are slipped. Also, very few decorated Wari ceramics are found beyond the summit of Cerro Baúl (see below). Since these vessels are so rare, they may have been reserved for a special use.

\section{The Use of Decorated Pottery}

Susan Bergh (2012) recently curated an exhibition with a broad sample of Wari pottery and other items. The collection demonstrates a variety of regional styles, differences in quality, and vessel types. The majority of these vessels were presumably used during feasts as containers for displaying large quantities of food or chicha, mediumsized jars to pour chicha, or as personal vessels for drinking and eating (Nash 2012a). Some types of Wari pottery may have held sacred value as religious paraphernalia (Cook 2004; Glowacki 2012). Menzel (1968) divided pottery into three classes based on its quality and the iconographic themes it illustrated: ceremonial, lay elite, and secular. Although some motifs may have had more secular affiliations, it may not be appropriate to use the perceived quality of manufacture to determine the affiliation and use of decorated Wari pottery. The recently recovered materials from the Vegachayoq sector or "Templo Mayor" at Huari provide insightful examples. Many vessels depos- 
ited as offerings in what is presumed to have been one of the most sacred places in the empire might be judged as low- or even mediocre quality based on the regularity of vessel shape, the execution of the motifs, and the uniformity of color (see Ochatoma et al. 2015:63-69).

At Cerro Baúl, cups and bowls were made in pairs or sets of four (Moseley et al. 2005: fig. 7; Nash 2012a: fig. 68). Such sets have been found in funerary and ritual deposits at other sites (e.g., Huari: Cabrera and Ochatoma 2016:294, fig. 3; Cantayo: Carmichael 1998:251, fig. 401; Castillo de Huarmey: Przadka Giersz 2014:116-17, fig. 69; San Jose de Moro: Castillo et al. 2012:58, fig. 3). At Cerro Baúl, some sets are decorated with abstract designs; others are decorated with the head of the front-face deity (see Moseley et al. 2005: fig. 8). Among museum collections, modeled polychrome vessels show individuals holding and seemingly toasting with cups (e.g., Nash 2012a: fig 59). These representations may correspond to drinking, but they could depict ritual toasting or the pouring of libations, which were important during Inka

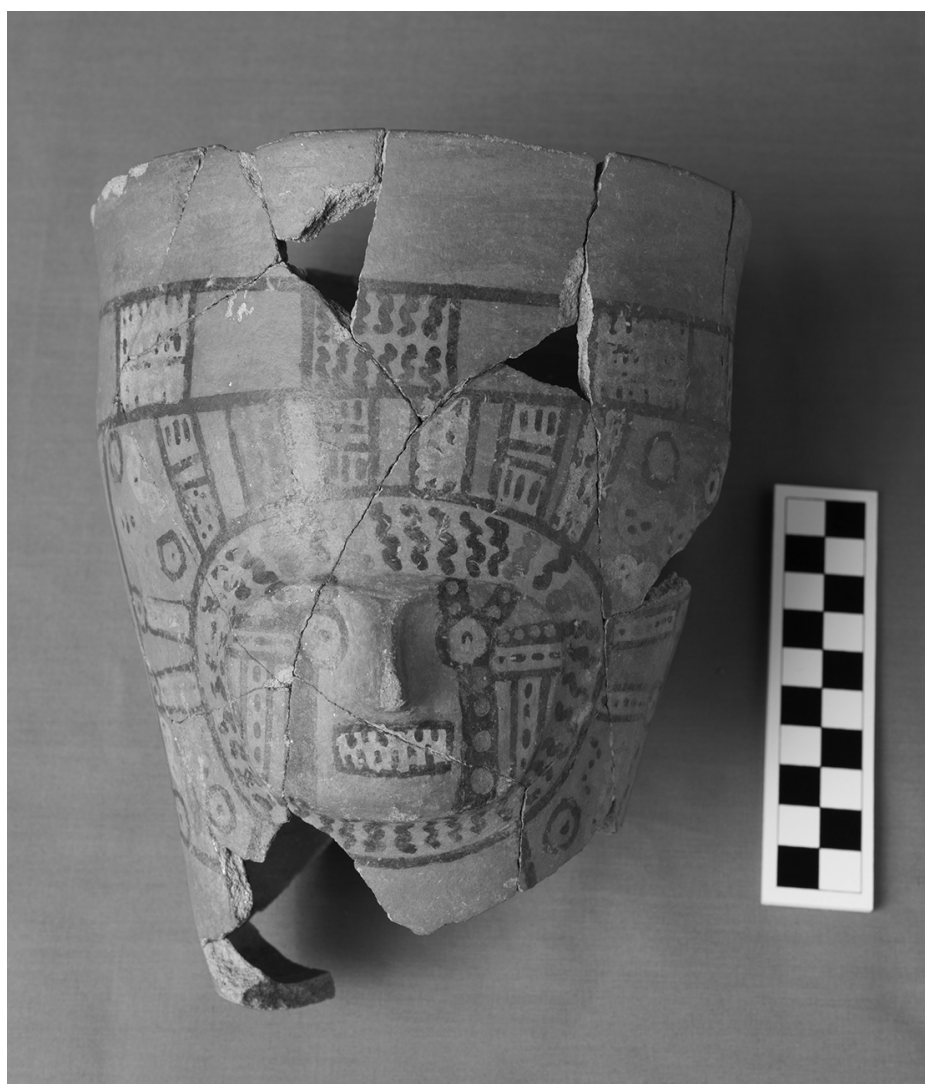

Figure 7. A vessel decorated with the front-face deity's head or a rayed head. (Photo by Jeff Clarke) 
times. Chicha was poured into drains for supernatural forces or offered to ancestors. Guamán Poma’s (2009:190, 193, 225, 231) illustrated chronicle shows that libations and toasting were both elements of many Andean rituals. Perhaps particular vessels were components of liturgical sets for these practices.

Elaborate decorated Wari pottery has been recovered from ritual deposits, where the vessels were purposely smashed. The ritual smashing of pottery is a widespread phenomenon that has been identified at many Wari sites (Cook 1987; Glowacki 2005, 2012). These deposits can contain vessels of different types and at times include fine, but undecorated, vessels (see Isbell 2000). Thus, perhaps some types of ceramic vessels were essential ingredients in these ritual offerings, or these deposits may represent the decommissioning of liturgical sets. In either case, vessels were required to perform regular offerings, which may have been affiliated with the ritual calendar or personalized rites of passage.

Decorated pottery on Cerro Baúl is affiliated with the ritual abandonment of several structures. Almost all Wari polychrome vessels have been found smashed. ${ }^{6}$ These were deposited in clusters, where most pieces of a vessel are present, but the pieces of a vessel may be divided between two clusters in a room or purposely placed in multiple rooms (Nash and deFrance 2019). Such deposits have been found on the latest occupied floor, with or without burning, and in association with earlier floors (Moseley et al. 2005). Decorated fragments are also found as solitary sherds in shallow offering pits with whole obsidian points, metal, and semiprecious stone. Groleau (2009) has suggested that some Wari sherds were collected during rituals in which vessels were smashed and later incorporated into pit offerings at Conchopata. This pattern is consistent with finds on Cerro Baúl (Nash and deFrance 2019).

\section{The Distribution of Decorated Wari Pottery}

Small groups gathered for feasts in some contexts on Cerro Baúl, Cerro Mejía (Nash 2010), and Cerro Trapiche (Green and Goldstein 2010). During these events, decorated Wari pottery was used and on display. Based on traditional models, such vessels would be distributed as gifts to solidify relations between patrons and clients or build alliances between neighboring groups (i.e., Wari and Tiwanaku). If decorated pottery was regularly gifted in this way, let's presume annually, then there should be concentrations of Wari decorated pottery in elite residential contexts at Tiwanaku and Chirabaya sites in the valley. There would also be decorated vessels in the houses of elite subordinates living on Cerro Mejía and Cerro Trapiche, as well as in the houses of local leaders at such Huaracane communities as Yahuay Alta, which was also occupied during the Middle Horizon.

Paul Goldstein (2005) has been working in Moquegua's middle valley for more than thirty years. He directed systematic survey of the area and has led excavations at several Tiwanaku sites. He has concluded that Wari and Tiwanaku had very little contact because he has found so few fragments of Wari pottery during his research. Likewise, Bruce Owen identified very few examples of Wari pottery in his survey of 
the coastal valley (Owen 2012). A few Wari vessels or Wari-Tiwanaku hybrids have been recovered from Tiwanaku tombs at Chen Chen and the later occupation at Tumilaca la Chimba (Sharratt 2011); however, tombs in some sense are ritual deposits, and it is difficult to assess what social processes are behind the deposition of these vessels in these funerary contexts.

Several Wari-affiliated sites have been identified and excavated in the vicinity of Cerro Baúl. This work uncovered very few decorated sherds, which are extremely rare outside the elite confines of Cerro Baúl. The site of Cerro Mejía has been a major part of my research program, and I have described the connections between the two sites (Nash 2010; Nash and Williams 2009). Mejía's summit has many large, monumental structures, presumably elite housing for groups ranking lower than those on Cerro Baúl. If ceramic vessels were distributed to followers, decorated pottery should be found in the elite residences on Cerro Mejía, but this is not the case.

Apparently, whole vessels were not routinely gifted to subordinates and imitations were not produced for circulation among low-ranking elites (Table 1). Assemblages from domestic contexts at Cerro Trapiche replicate the pattern at Cerro Mejía (Green 2015:455-57, 464). ${ }^{7}$ Yahuay Alta had no Wari sherds (Costion 2009). In contrast, more than $50 \%$ of the decorated sherds from the palace context at Baúl pertain to vessels that can be reconstructed to a great degree (Figure 7). The decorated sherds found at Cerro Mejía, however, are single, isolated sherds and may have been distributed as such during ritual events (see Groleau 2009). The assemblages from two elite compounds on Mejía's summit do not include the smashed remains of whole decorated vessels, which means these items were not used in the same manner by lower-ranking elites. In the Baúl palace, decorated pottery was concentrated in the Wari patio group. One of the elite compounds on Mejía's summit is monumental, has a similar design to Baul's sector A palace, and is nearly as large. Yet, excavations of the Wari patio group in this structure failed to uncover fragments of decorated vessels.

The distribution of Wari finewares in Moquegua does not coincide with a pattern representing exchange or gifting to form alliances as motivation for production. Instead, this limited distribution supports the possibility that fine, decorated vessels may have been singular objects produced as insignia displayed during political gatherings (Cook and Glowacki 2003), or as sacred paraphernalia used during rituals. If elites of subordinate rank received decorated wares, they must have become grave goods or have been deposited in ritual contexts. These lower-ranking elites did not receive vessels in sufficient numbers to pass them on to subordinates. It also appears they were not sanctioned to use them in their own domestic offerings; undecorated wares or those of another affiliation were smashed on the floors instead (Nash 2012b).

\section{DISCUSSION}

The current data support the hypothesis that elite occupants of the sector A palace on Cerro Baúl elected to produce pottery as an elite strategy in the cultural context of Middle Horizon Moquegua. If some pottery had sacred value, perhaps Wari elites 


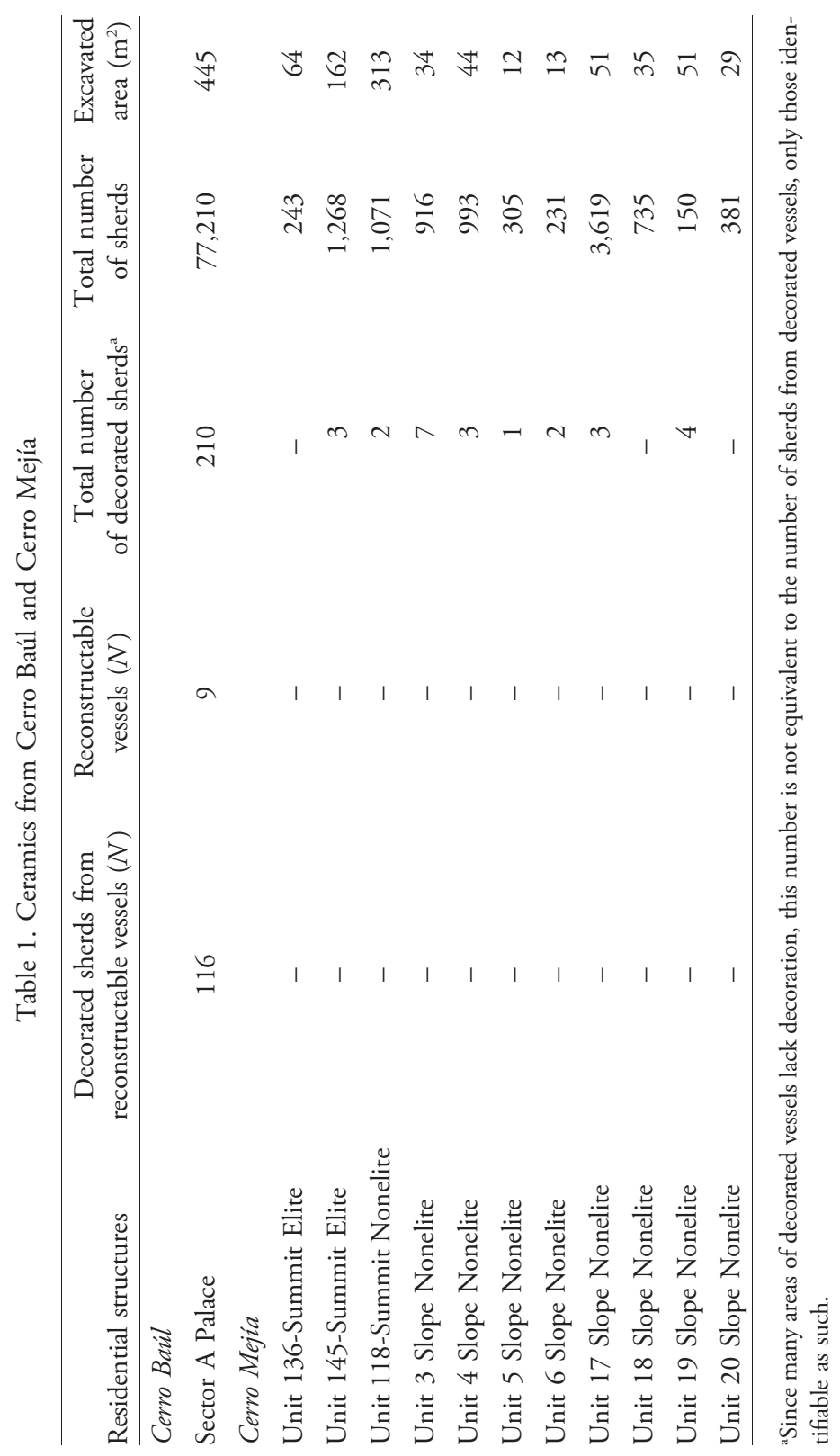


controlled this technology where possible. At the time of Wari intrusion in Moquegua, local groups were not making polychrome pottery (Goldstein 2000) and may have lacked the technology to do so. Therefore, Wari elites could monopolize production and introduce these items as sacred goods during dramatic ritual performances. As singular objects, some types of Wari pottery could have projected the power of state officials in a number of ways.

Some vessels may have represented individuals (Cook and Glowacki 2003) or a particular role, such as an insignia of office. Knobloch (2016:115, n. 11) has noted the similarity between two bottles found in the elite tombs at Castillo de Huarmey and Espiritu Pampa, two sites that are more than $600 \mathrm{~km}$ apart. One of the most parsimonious explanations has the two interred personages as collaborating elites holding a particular office in these distant provinces. Interestingly, these two burial assemblages, which include quantities of valuable metal, contained relatively few decorated ceramic vessels.

Other vessels may have been components of liturgical sets used by leaders on certain occasions. Elites could manipulate ritual paraphernalia in the form of matching cups and bowls to pour libations or toast supernaturals (e.g., mountain apu, the sun, ancestors). Tombs in the Nasca region and those at San Jose de Moro have Wari or "Wari influenced" vessel sets of this kind. Iconographic schemes may have corresponded with events of the religious calendar or rites of passage, such as puberty, marriage, assumption of office, or funerals. Decorated vessels do not seem to have been simply a valuable that could be exchanged indiscriminately or redistributed to subordinates. There may have been sumptuary laws or religious sanctions barring ownership without authorization. Only one vessel or a ritual set of vessels would be given to a Wari official (or elite couple, see Nash 2010:104, n. 1, 2012a:88) as insignia or ritual paraphernalia to perform their designated role These items would accompany people to their graves or be ceremonially decommissioned and ritually deposited. The elite artisans who created these objects could monopolize ritual and bestow privileges on select subordinates.

As Spielmann (1998) suggests, individuals may choose to produce sacred goods when ritual is a potent source of power. In the context of an expansive polity, provincial elites had to rely on multiple strategies to establish authority over conquered groups. The resources to produce large quantities of food and chicha for gatherings and offerings, as well as ritually destroy vessels and other goods, could be channeled toward usurping the veneration of chthonic forces (Williams and Nash 2006) or ancestors (Green and Goldstein 2010). Further, keeping technologies secret, such as how to paint and fire polychrome vessels, may have permitted elites to monopolize the production of items with symbolic or sacred value.

Alternatively, if ceramic vessels were insignia of rank, these symbols presumably came with defined privileges and powers. Provincial leaders may not have had to routinely distribute such goods. Perhaps all that was needed was the threat of taking such a singular and powerful symbol away. If decorated vessels did represent persons and their 
ranks, the production of replicas, even if the technology was widely available, may have violated sumptuary laws.

\section{CONCLUSIONS}

If some vessels were insignia representing the ranks of Wari officials or sacred objects used in rituals, then elite producers were not just making objects that symbolized power but were essentially creating power itself (see Kopytoff 1999). Such items would not be made in large quantities, and they might not ever leave the household. The examples I have reviewed in this paper-Ames's gitsonkt mask makers, Spielmann's ritual specialists in the Southwest, and Inomata's elite specialists at Aguateca-show that some specialists craft to empower themselves and their kin group. I would argue that the data from the sector A palace put the elite household on Cerro Baúl in this category. This particular pattern cross-cuts the relative complexity of the group and does not pertain to all relations of production for the entire society. It is not an example of embedded specialization. For this reason, I would propose that some societies may have elite craft specialists that engage in production to create items such as insignia, regalia, and ritual paraphernalia. These items may be used by members of the household or be distributed in a very limited way. In either case, their production and use were essential elements of the political economy and as such these important relations of production should be highlighted, described, and studied through crosscultural comparison.

More broadly, the relations of production, use, and meaning of an item need to be determined rather than assumed in archaic states. Rare or seemingly precious goods may not all play the same role in the polity's political economy. If an item was not regularly distributed to subordinate elites during feasting or ritual events, but rather was a singular good, then other lines of evidence should be given equal or more weight. Studying changes in settlement patterns, the distribution of commodities, or the appearance of imperial technologies may be more appropriate when trying to determine the extent and nature of an empire's hegemony.

\section{NOTES}

This paper would not have been possible without the assistance and support of many people. The research has taken many years and followed several avenues of inquiry. Funding has been provided from the National Science Foundation, the National Endowment for the Humanities, the Heinz Family Foundation, the American Philosophical Society, and the University of North Carolina Greensboro. I would like to thank the students who assisted with the excavations on Cerro Baúl-Sofia Chacaltana, Caleb Kestle, Jim Meierhoff, Nicola Sherratt, Ben Vining, Kirk Costion, and Robin Coleman — as well as the project PIs: Michael Moseley and Ryan Williams. I am also grateful to the students who have worked with me to reconstruct the smashed vessels from the palace and document the materials related to ceramic production, including 
Miranda Fleming, Phillip Blattenberger, Mallery Lutey, Megan Chamberlain, Chelsea Brown, Maya Moseley, John Hicks, Kate Huggins, Adam Stack, Rachel Maass, Ann Laffey, Erin Parsons, Louis Fortin, David Reed, and Cyrus Banikazemi, as well as our invaluable local lab technician Maria Ascero Condori. I would also like to thank the staff of Museo Contisuyo for their assistance and logistical support during the several years of lab analysis. I also appreciate the great advice I received regarding the pottery production materials and technology from Mario Ruales and Dean Arnold, as well as Miranda Fleming and Michael Wylde for their help with experimental studies. I also sincerely appreciate the comments and suggestions I have received on the numerous drafts of this paper from Susan deFrance, Rick Sutter, Joanne Murphy, Ryan Williams, Curran Fitzgerald, Chandler Jarboe, Lawrence Straus, and several anonymous reviewers. Any errors, of course, are my own.

1. I use "affiliated" as a neutral term to describe people in the empire who are not from the imperial heartland. The concept of affiliation acknowledges that people would maintain aspects of their regional identities. Conquered groups would not rapidly change to imitate features in the capital, and "Wari-ization" may not take place in provinces of the empire.

2. Ochatoma (2007) has published detailed maps of the contexts in which production tools (e.g., molds for face neck jars, potters' plates, etc.) were found. In many instances these items were ritually deposited along with other valued goods in pit offerings (see Groleau 2009). This pattern can frustrate efforts to determine exactly where production took place; however, if we view a residential compound as a discrete unit of ritual deposition and presume that objects deposited through ritual abandonment of a house were goods used by the household, then we can associate the use of tools and other items to household units. For further consideration of this issue see Nash 2010 and Nash and deFrance 2019.

3. Publications by Perez (1998), Perez and Ochatoma (1998), and Ochatoma (2007) include sufficient details to evaluate the use of space from features rather than from the frequencies of decontextualized artifacts. Also, Wolff (2012) identified additional production areas that Tschauner and Isbell's (2012) analysis did not rule out as potential areas of production.

4. During surface collection of the terrace we recovered 1,510 pieces of chrysacolla weighing $110.7 \mathrm{~g}$ and 2,360 pieces of sodalite weighing $2571.8 \mathrm{~g}$.

5. The quality was coded based on the presence of white inclusions; "high quality" corresponded to pieces with no inclusions.

6. Intact vessels are most commonly found in tombs. Excavations on Cerro Baúl have uncovered few tombs.

7. Structure 3 at Cerro Trapiche appears to have been associated with chicha production (Green and Goldstein 2010). The Wari style pottery found in this space may pertain to entire vessels and may be part of a ritual deposit like that found in the brewery on Cerro Baúl. 


\section{REFERENCES CITED}

Allen, Catherine. 1988. The hold life has. Washington, DC: Smithsonian Institution. Ames, Kenneth. 1995. "Chiefly power and household production on the Northwest Coast," in Foundations of social inequality. Edited by T. Douglas Price and Gary Feinman, pp. 155-88. New York: Plenum.

Anders, Martha, Susana Arce, Izumi Shimada, Victor Chang, Luis Tokuda, and Sonia Quiroz. 1998. "Early Middle Horizon pottery production at Maymi, Pisco Valley Peru," in Andean ceramics: Technology, organization, and approaches. Edited by Izumi Shimada, pp. 233-52. Philadelphia: MASCA, University of Pennsylvania Museum of Archaeology and Anthropology.

Ángeles Falcón, Rommel. 2008. "Del intermedio temprano al horizonte medio: Una visión de la costa centro Sur desde el valle de asia," in Arqueología de la costa centro sur Peruana. Edited by Omar Piendo and Henry Tantaleán, pp. 103-46. Lima: Avqi Ediciones.

Bencic, Catherine. 2000. Industrias líticas de Huari y Tiwanaku. Boletín de Arqueología PUCP 4:89-118.

Bergh, Susan, ed. 2012. Wari: Lords of the ancient Andes. New York: Thames and Hudson.

Bray, Tamara. 2009. An archaeological perspective on the Andean concept of camaquen: Thinking through late pre-Columbian ofrendas and huacas. Cambridge Archaeological Journal 19:35766.

Brumfiel, Elizabeth, and Timothy Earle. 1987. "Specialization, exchange, and complex societies: An introduction," in Specialization, exchange, and complex polities. Edited by Elizabeth Brumfiel and Timothy Earle, pp. 1-9. Cambridge: Cambridge University Press.

Buxeda i Garrigós, Jaume, and Francisco Tuset Bertran. 2010. "Las producciones altoimperiales de Terra Sigillata Hispanica Dorada (TSHD) y Terra Sigillata Hispanica (TSH) de Clunia según su caracterización arqueométrica," in VIII Congreso Ibérico de Arqueometría: Actas. Edited by Esperanza Saiz Carrasco, Raúl López Romero, Ascensión Cano Díaz-Tendero, and Juan Carlos Calvo García, pp. 49-56. España: Seminario de Arqueología y Etnología Turolense.

Cabrera R., Martha, and José Ochatoma P. 2016. "El Estilo Huamanga: Formas e iconografía de la cerámica doméstica durante el imperio Wari," in Nuevas perspectivas en la organización política Wari. Edited by Miłosz Giersz and Krzysztof Makowski, pp. 287-330. Andes: Boletin del Centro de Estudios Precolombinos de la Universidad de Varsovia No. 9. Varsovia: Centro de Estudios Precolombios.

Carmichael, Patrick, ed. 1998. The archaeology and pottery of Nasca, Peru: Alfred L. Kroeber's 1926 expedition. London. Alta Mira.

Carter, Tristan. 2004. Transformative processes in liminal spaces: Craft as ritual action in the Throne Room area. British School at Athens Studies 12:273-82.

Castillo B., Luis Jaime, Francesca Fernandini P., and Luis Muro Y. 2012. The multidimensional relations between the Wari and the Moche states of northern Peru. Boletin de Arqueologia PUCP 16:53-77.

Christie, Jessica. 2006. "Houses of political power among the ancient Maya and Inka," in Palaces and power in the Americas: From Peru to the Northwest Coast. Edited by J. Christie and P. Sarro, pp. 353-96. Austin: University of Texas Press.

Christie, Jessica, and Patricia Sarro, eds. 2006. Palaces and Power in the Americas: From Peru to the Northwest Coast. Austin: University of Texas Press.

Cook, Anita. 1987. The Middle Horizon ceramic offerings from Conchopata. Nawpa Pacha 22-23:49-90. 
2004. "Wari art and society," in Andean archaeology. Edited by Helaine Sliverman, pp. 146-66. Oxford: Blackwell.

Cook, Anita, and Nancy Benco. 2000. Vasijas para la fiesta y la fama: Producción artisanal en un centro urbano Huari. Boletin de Arqueología PUCP 4:489-504.

Cook, Anita, and Mary Glowacki. 2003. "Pots, politics, and power: Huari ceramic assemblages and imperial administration," in The archaeology and politics of food and feasting in early states and empires. Edited by Tamara Bray, pp. 173-202. New York: Kluwer Academic.

Costin, Cathy. 1991. "Craft specialization: Issues in defining, documenting, and explaining the organization of production," in Archaeological method and theory 4. Edited by Michael Schiffer, pp. 1-56. Tucson: University of Arizona Press.

. 1998. Introduction: Craft and social identity. Archeological Papers of the American Anthropological Association 8(1):3-16.

Costion, Kirk. 2009. Huaracane social organization: Change over time at the prehispanic community of Yahuay Alta, Peru. PhD dissertation, University of Pittsburgh.

Covey, R. Alan., Brian S. Bauer, Véronique Bélisle, and Lia Tsesmeli. 2013. Regional perspectives on Wari state influence in Cusco, Peru (c. AD 600-1000). Journal of Anthropological Archaeology 32:538-52.

Crown, Patricia. 2001. Learning to make pottery in the prehispanic American Southwest. Journal of Anthropological Research 57:451-69.

D'Altroy, N. Terrence, and R. L. Bishop. 1990. The provincial organization of Inka ceramic production. American Antiquity 55:120-38.

D'Altroy, N. Terrence, and Timothy K. Earle. 1985. Staple finance, wealth finance, and storage in the Inka political economy. Current Anthropology. 26:187-206.

deFrance, Susan. 2014. "The luxury of variety: Animals and social distinction at the Wari site of Cerro Baúl, southern Peru," in Animals and inequality in the ancient world. Edited by S. McCarty and B. Arbuckle, pp. 63-84. Boulder: University Press of Colorado.

Earle, Timothy, and Justin Jennings. 2012. Remodeling the political economy of the Wari Empire. Boletin de Arqueología PUCP 16:209-25.

Feinman, Gary, and Linda M. Nicholas. 2004. "Unraveling the prehispanic highland Mesoamerican economy: Production, exchange, and consumption in the Classic period Valley of Oaxaca," in Archaeological perspectives on political economies. Edited by Gary Feinman and Linda Nicholas, pp. 1-6. Salt Lake City: University of Utah Press.

2007. "Household production and the regional economy in Ancient Oaxaca: Classic period perspectives from hilltop El Palmillo and valley-floor Ejutla" in Pottery economics in Mesoamerica. Edited by Christopher Pool and George Bey, pp. 184-211. Tucson: University of Arizona Press.

Flannery, Kent. 1998. "The ground plans of archaic states," in Archaic states, Edited by Gary Feinman and Joyce Marcus, pp.15-57. Santa Fe: School of American Research.

Glatz, Claudia. 2013. "Negotiating empire: A comparative investigation into the responses to Hittite imperialism by the vassal state of Ugarit and the Kaska peoples of Pontic Anatolia," in Empire and diversity. Edited by G. Areshian, pp. 21-56. Los Angeles: Cotsen Institute of Archaeology, UCLA.

Glowacki, Mary. 2005. "Pottery from Pikillacta," in Pikillacta: The Wari empire in Cusco. Edited by Gordon McEwan, pp. 101-14. Iowa City: Iowa University Press. 
2012. "Shattered ceramics and offerings," in Wari: Lords of the ancient Andes. Edited by Susan Bergh, pp. 145-58. London: Thames and Hudson.

Gluckman, Max. 1983. "Essays on Lozi land and royal property," in Research in economic anthropology 5. Edited by George Dalton, pp. 1-94. Greenwich, CT: JAI Press.

Godelier, Maurice. 1977. Perspectives in Marxist anthropology. Cambridge: Cambridge University Press.

1999. The enigma of the gift. Chicago: University of Chicago Press.

Goldstein, Paul. 2000. Exotic goods and everyday chiefs: Long-distance exchange and indigenous sociopolitical development in the South Central Andes. Latin American Antiquity 11:335-61.

-2005. Andean diaspora: The Tiwanaku colonies and the origins of South American empire. Gainesville: University Press of Florida.

Gose, Peter. 1986. Sacrifice and the commodity form in the Andes. Man 21:296-310.

Green, Ulrike. 2015. Cerro Trapiche and the Wari frontier experience in the Middle Moquegua Valley, Perú. PhD dissertation, University of California, San Diego.

Green, Ulrike, and Paul Goldstein 2010. "The nature of Wari presence in the Mid-Moquegua Valley: Investigating contact at Cerro Trapiche," in Beyond Wari walls: Regional perspectives on Middle Horizon Peru. Edited by Justin Jennings, pp. 19-36. Albuquerque: University of New Mexico Press.

Groleau, Amy. 2009. Special finds: Locating animism in the archaeological record. Cambridge Archaeological Journal 19:398-406.

Guamán Poma de Ayala, Felipe. 2009. The first new chronicle and good government: On the history of the world and the Incas up to 1615. Translated and edited by Roland Hamilton. Austin: University of Texas Press.

Hirth, Kenneth G. 2009. "Household, workshop, guild, and barrio: The organization of obsidian craft production in a prehispanic urban center," in Domestic life in prehispanic capitals: A study of specialization, hierarchy, and ethnicity. Edited by Linda Manzanilla and Claude Chapdelaine, pp. 43-66. Ann Arbor: Regents of the University of Michigan.

Inomata, Takeshi. 2001. The power and ideology of artistic creation: Elite craft specialists in Classic Maya society. Current Anthropology 42:321-33.

2007. "Classic Maya elite competition, collaboration, and performance in multicraft production," in Craft production in complex societies: Multicraft and producer perspectives. Edited by Izumi Shimada, pp. 120-36. Salt Lake City: University of Utah Press.

Inomata, Takeshi, and Steven Houston. 2001. Royal courts of the ancient Maya, 1. Boulder, CO: Westview Press.

Isbell, William. 1989. "Honcopampa: Was it a Huari administrative centre?" in Nature of Wari: A reappraisal of the Middle Horizon period in Peru. Edited by R. M. Czwarno, F. M. Meddens, and A. Morgan, pp. 98-114. BAR International Series. No. 525. Oxford: Archaeopress.

1991. Huari administration and the orthogonal cellular architecture horizon," in Huari administrative structure. Edited by William Isbell and Gordon McEwan, pp. 293315. Washington, DC: Dumbarton Oaks.

2000. Repensando el Horizonte Medio: El caso de Conchopata, Ayacucho, Perú. Boletin de Arqueología PUCP 4:9-68.

- 2007. "A community of potters or multicrafting wives of polygynous lords?" in Craft production in complex societies: Multicraft and producer perspectives. Edited by Izumi Shimada, pp. 68-96. Salt Lake City: University of Utah Press. 
Isbell, William, Christina Brewster-Wray, and Linda Spickard. 1991. "Architecture and spatial organization at Huari," in Huari administrative structure. Edited by William Isbell and Gordon McEwan, pp. 19-53. Washington, DC: Dumbarton Oaks.

Isbell, William, and Anita Cook. 1987. Ideological origins of an Andean conquest state. Archaeology 40(4):26-33.

Janusek, John. 1999. Craft and local power: Embedded specializations in Tiwanaku cities. Latin American Antiquity 10:107-31.

Keeley, Helen, and Frank Meddens. 1993. Prehispanic agricultural terraces in the Chica/Soras Valley, Peru. Institute of Archaeology Bulletin 29:121-38.

Knobloch, Patricia. 2016. "La vida y los tiempos de El Señor Wari de Vilcabamba: Cronología e identidad del Agente 103 en el imperio Wari durante el Horizonte Medio," in Nuevas perspectivas en la organización politica Wari. Edited by Miłosz Giersz and Krzysztof Makowski, pp. 91-120. Andes: Boletin del Centro de Estudios Precolombinos de la Universidad de Varsovia No. 9. Varsovia: Centro de Estudios Precolombios.

Kopytoff, Igor. 1986. "The cultural biography of things: Commoditization as process," in The social life of things; Commodities in cultural perspective. Edited by Arjun Appadurai, pp. 6491. Cambridge: Cambridge University of Press.

1999. "The Aghem chiefdoms of western Cameroon," in Beyond chiefdoms: Pathways to complexity in Africa. Edited by Susan Keech McIntosh, pp. 88-96. Cambridge: Cambridge University Press.

Lau, George F. 2005. Core-periphery relations in the Recuay hinterlands: Economic interaction at Chinchawas, Peru. Antiquity 79:78-99.

Leoni, Juan. 2006. "Ritual and society in early intermediate period Ayacucho: A view from the site of Nawinpukyo," in Andean archaeology III. Edited by William Isbell and Helaine Silverman, pp. 279-306. New York: Springer.

Lumbreras, Luis. 1990. Visión arqueolóica del Perú milenario. Lima: Editorial Milla Batres.

Mauss, Marcel. 1990. The gift. Translated by W. Halls. London: W.W. Norton.

Mayer, Enrique. 2002. The articulated peasant. Boulder, CO: Westview.

McAnany, Patricia. 1993. "The economics of social power and wealth among eighth-century Maya households," in Lowland Maya civilization in the eighth century A.D. Edited by Jeremy Sabloff and John Henderson, pp. 65-89. Washington, DC: Dumbarton Oaks.

McEwan, Gordon. 2005. Pikillacta: The Wari empire in Cuzco. Iowa City: Iowa University Press.

Menzel, Dorothy. 1968. New data on the Wari empire in Middle Horizon 2A. Nawpa Pacha 6:47-114.

Morris, Craig., R. Alan Covey, P. Stein, P. 2011. The Huánaco Pampa Archaeological Project, vol. 1: The plaza and palace complex. New York: Anthropological Papers of the American Museum of Natural History 96.

Moseley, Michael, Donna Nash, P. Ryan Williams, and Susan D. deFrance. 2005. Burning down the brewery: Establishing and evacuating an ancient imperial colony at Cerro Baúl, Peru. Proceedings of the National Academy of Sciences 102(48):17264-71.

Nash, Donna. 2002. The archaeology of space: Places of power in the Wari empire. PhD dissertation, University of Florida, Gainesville.

_ 2010. "Fine dining and fabulous atmosphere: Feasting facilities and political interaction in the Wari realm," in Inside ancient kitchens: New directions in the study of daily meals 
and feasting events. Edited by Elizabeth Klarich, pp. 83-110. Boulder: University of Colorado Press.

. 2012a. "The art of feasting: Building an empire with food and drink," in Wari: Lords of the ancient Andes. Edited by Susan Burgh, pp. 82-101. New York: Cleveland Museum of Art and Thames and Hudson.

2012b. El establecimiento de relaciones de poder a través del uso del espacio residencial en la provincia Wari de Moquegua. Bulletin de l'Institut d'Estudes Andines 41(1):1-34.

Nash, Donna, and R. Monika Barrionuevo. 2008. El Proyecto Arqueológico Asentamientos en Cerro Mejía, 2008 (ACME). Report submitted to INC of Peru. https://libres.uncg .edu/ir/uncg/listing.aspx?styp $=\mathrm{ti} \& \mathrm{id}=9811$.

Nash, Donna, and Susan deFrance. 2019. Plotting abandonment: Excavating a ritual deposit at the Wari site of Cerro Baúl. Journal of Anthropological Archaeology 53:112-32.

Nash, Donna, and P. Ryan Williams. 2005. Architecture and power: Relations on the WariTiwanaku frontier. Archaeological Papers of the American Anthropological Association 14:151-74. . 2009. "Wari political organization on the southern periphery," in Andean civilization: A tribute to Michael E. Moseley. Edited by Joyce Marcus and Patrick Ryan Williams, pp. 257-76. Los Angeles: Cotsen Institute of Archaeology Monograph 63.

Nelson, M., D. Glowacki, and A. Smith. 2002. "The impact of women on household economies: A Maya case study," in In pursuit of gender: Worldwide archaeological approaches. Edited by Sarah Milledge Nelson and Myriam Rosen-Ayalon, pp. 125-54. Walnut Creek, CA: Alta Mira Press.

Ochatoma P., Jose. 2007. Alfareros del imperio huari: Vida cotidian y areas de actividad en Conchopata. Lima: Universidad Nacional de San Cristóbal de Huamanga.

Ochatoma P. José, Martha Cabrera R., and Carlos Mancilla R. 2015. El área sagrada de Wari: Investigaciones arqueológicas en Vegachayuq Moqo. Ayacucho: Universidad Nacional de San Cristóbal de Huamanga.

Owen, Bruce. 2007. Rural Wari far from the heartland: Huamanga ceramics from Beringa, Majes Valley, Peru. Andean Past 8:287-373.

2012. Ceramic and textile evidence of Wari interactions with Osmore drainage populations from the sierra to the coast. Paper presented at the $77^{\text {th }}$ annual meeting of the Society for American Archaeology, Memphis.

Peregrine, Peter. 1991. Some political aspects of craft specialization. World Archaeology 23:1-11. Perez, Ismael. 1998. Excavación y definición de un taller de alfareros Huari, Conchopata. Conchopata: Revista de Arqueología 1:93-137.

Perez, Ismael, and Jose Ochatoma. 1998. Viviendas, talleres y hornos de produccion alfarera Huari en Conchopata. Conchopata: Revista de Arqueología 1:72-92.

Pillsbury, Joanne, and Banks Leonard. 2004 "Identifying Chimu palaces: Elite residential architecture in the Late Intermediate Period," in Palaces of the ancient New World. Edited by Susan Toby Evans and Joanne Pillsbury, pp. 247-98. Washington, DC: Dumbarton Oaks. Pozzi-Escot, Denise, Marleni Alarcón, and Cirilo Vivanco. 1993. Instrúmentos de alfáreros de la época Wari. Bulletin de l'Institut français d'etudes andines 22:467-96

Przadka Giersz, Patrycja. 2014. "Ajuar personal: Las mujeres de la élite wari y su atuendo," in Castillo de Huarmey: El mausoleo imperial Wari. Edited by Milosz Giersz, pp. 100-27. Lima: Asociación Museo de Arte de Lima. 
Reents-Budet, Dorie. 1998. Elite Maya pottery and artisans as social indicators. Archeological Papers of the American Anthropological Association 8(1):71-89.

Rehfisch, F. 1987. "Competitive beer drinking among the Mambila," in Constructive drinking: Perspectives on drink in anthropology. Edited by Mary Douglas, pp. 135-45. Cambridge: Cambridge University Press.

Rosas Rintel, Marco. 2007. Nuevas perspectivas acerca del colapso Moche en el Bajo Jequetepeque: Resultados preliminares de la segunda campaña de investigación del proyecto arqueológico Cerro Chepén. Bulletin de l'Institut Français d'études Andines 36:221-40

Sahlins, Marshall. 1972. Stone Age economics. Chicago: Aldine Atherton.

Salomon, Frank. 1998. How the Huacas were: The language of substance and transformation in the Huarochirí Quechua Manuscript. RES: Anthropology and Aesthetics: Pre-Columbian States of Being 33:7-17.

Salomon, Frank, and George L. Urioste, trans. 1991. The Huarochiri manuscript: A testament of ancient and colonial Andean religion. Austin: University of Texas Press.

Schortman, Edward, and Patricia A. Urban. 2004. Modeling the roles of craft production in ancient political economies. Journal of Archaeological Research 12(2):185-226.

Schreiber, Katharina. 1992. Wari imperialism in Middle Horizon Peru. Ann Arbor: University of Michigan Press.

- 2005. Sacred landscapes and imperial ideologies: The Wari empire in Sondondo, Peru. Archaeological Papers of the American Anthropological Association 14:131-50.

Sharratt, Nicola. 2011. Social identities and state collapse: A diachronic study of Tiwanaku burials in the Moquegua Valley, Peru. PhD dissertation, University of Illinois, Chicago.

Sharratt, Nicola, Mark Golitko, Ryan Williams and Laure Dussubieux. 2009. Ceramic production during the Middle Horizon: Wari and Tiwanaku clay procurement in the Moquegua Valley, Peru. Geoarchaeology 24(6):792-820.

Spielmann, Katherine. 1998. Ritual craft specialists in middle-range societies. Archeological Papers of the American Anthropological Association 8(1):153-59.

Stanish, Charles. 2003. Ancient Titicaca: The evolution of complex society in southern Peru and northern Bolivia. Los Angeles: University of California Press.

Topic, John. 2009. "Domestic economy as political economy at Chan Chan, Perú," in Domestic life in prehispanic capitals: A study of specialization, hierarchy, and ethnicity. Edited by Linda Manzanilla and Claude Chapdelaine, pp. 221-42. Ann Arbor: Regents of the University of Michigan.

Tschauner, Hartmut, and William H. Isbell. 2012. Conchopata: Urbanismo producción artesanal e interacción interregional en el Horizonte Medio. Boletín de Arqueología PUCP 16:131-64.

Williams, P. Ryan. 2006. "Agricultural innovation, intensification, and sociopolitical development: The case of highland irrigation agriculture on the Pacific Andean watersheds," in $A g$ ricultural strategies. Edited by Joyce Marcus and Charles Stanish, pp. 309-33. Los Angeles: Cotsen Institute of Archaeology at UCLA.

Williams, P. Ryan, and Donna Nash. 2006. Sighting the apu: A GIS analysis of Wari imperialism and the worship of mountain peaks. World Archaeology 14:455-68.

_. 2016 "Religious ritual and Wari state expansion" in Ritual and archaic states. Edited by Joanne Murphy, pp. 131-56. Gainesville: University Press of Florida. 
Williams, P. Ryan, Donna Nash, Anita Cook, and William Isbell. 2019. "Assessing Wari ceramic production via INAA," in Ceramics of the indigenous cultures of South America: Production and exchange. Edited by Michael Glascock, Hector Neff, and Kevin Vaughn, pp. 125-33. Albuquerque: University of New Mexico Press.

Wolff, Barbara. 2012. Potters, power and prestige: Early Intermediate Period and Middle Horizon ceramic production at Conchopata, Ayacucho, Peru (A.D. 400-1000). PhD dissertation, Catholic University of America, Washington, DC. 